\title{
HERITAGE AND SUSTAINABLE DEVELOPMENT: CAPACITY BUILDING THROUGH TOURISM
}

ISABEL VAZ DE FREITAS ${ }^{1 *}$ and MICHAŁ RYSZARD KOSKOWSKI ${ }^{2}$

${ }^{1}$ Universidade Portucalense, Porto, Portugal, Research Group on Economics, Management and Information Technologies-REMIT

${ }^{2}$ Szkoła Główna Handlowa w Warszawie (Warsaw School of Economics), Warszawa, Poland

*Corresponding author. E-mail: ifc@upt.pt

\begin{abstract}
Heritage protection becomes an ever-greater challenge due to constant and numerous threats by natural elements and the sole passage of time. This deterioration is increased by other stress circumstances such as economic, social and development pressures, climate change, war, social and religious conflicts, and a number of other factors related to heritage use.

Heritage and historical landscapes should be preserved not only because of their role as an important testimony to bygone times and the source of a spirit of place, but because heritage and culture are important factors of territorial and economic development. Moreover, tourism is one of the sectors of economy that could improve the conservation of heritage and maintenance of cultural diversity. The study will facilitate an author review to complete the picture of the current situation and to find gaps; a documental analysis in order to capture the main concepts, compile the risks and opportunities from selected international and European documents as well as interviews with selected heritage stakeholders and professionals in relevant fields.
\end{abstract}




\subsection{INTRODUCTION}

Settled landscapes around the world are rich in resilient cultural elements (tangible and intangible), a sum of activities of earlier human generations. This continuous process results in an accumulation of cultural layers are expressions of a social diachronic perspective that mark the inheritance of today's living societies.

These layers are testimonies of emotions, beliefs, traditions, behaviors, and needs created and collected through human action with the passage of time. In this context, heritage as a cultural resource, material, and immaterial, has been among the key elements of most aspects of urban and rural landscapes. Foremost, heritage includes, as detailed in the Québec declaration (UNESCO, 2008), the tangible and intangible heritage, elements that carry memory. These tangible and intangible elements bequeath places with identity and character.

History, heritage, and culture are the past, present, and future landscape builders, working in a close interaction with communities and the nature itself. Monuments, sites, and intangible heritage are inseparable from the history and their setting. It is the time and places that give a character to heritage, and increase its intrinsic values (UNESCO, 1964).

It is necessary that cultural heritage, tangible or intangible, in macro and in micro places, should be protected and conserved for the use of future generations. This simple rule ensures that the knowledge contained in heritage and its capacity to testify to the diversity and history of the planet Earth is preserved. For the present generations, the cultural heritage is a human right in its diversity, access, and use (Universal Declaration of Human Rights, 1948).

As a testimony of human history and as a human right, the cultural value of heritage goes beyond its value as an economic asset. It is not only intrinsic but also extrinsic. As Fredheim and Khalafor, among other authors, mention that experts have different measures for the heritage values. Economists recognize its dynamic use and the cultural professionals distinguish the heritage values when heritage is both in use (use value) and when it is not in use (the non-use value). In that case, the value is reflected in the significance concept and the criteria (ICOMOS, 2013).

It is possible to find a balance between the economic and the cultural and historical perspective and contribute to sustainability by connecting 
the cultural and heritage conservation management practices with the economic exploitation of heritage. Heritage is an important component in economic development, in particular through tourism and other commercial activities, notably in rural areas, depopulated places, or economically and socially deprived zones. In this context, it is a priority to highlight the role of cultural conservation in economic and territorial development and to identify adequate methodologies to implement the economic perspective within the cultural management and preventive conservation practices to mitigate against heritage damage or destruction. Otherwise, the damage or disappearance of the cultural or natural heritage is a question of impoverishment (UNESCO, 1972). Moreover, the economic development of heritage as a territorial resource could be a very stimulating tool for its protection and conservation.

In this chapter, capacity building is understood as the capacity to promote abilities and competences development to achieve concrete objectives (ICOMOS, 2013). The main objective of the text is to develop sustainability and heritage conservation through a coordinated program between stakeholders.

As a research work integrated in REMIT (Research on Economics, Management and Information Technologies) at Portucalense University, it is dedicated to the study of sustainable heritage tourism and to debate methodologies that might improve the process of building stakeholder capacity to improve, in a formal or informal way, the sustainability of heritage tourism. The project intends to develop the following objectives:

a) Study and debate international charts and conventions, and the state of the art knowledge in order to create a conceptual framework based on the solid understanding of the concepts: "authenticity," "preservation for future generations," "heritage safeguarding," "universal values of cultural heritage," "heritage significance," "integrity," "identity," "diversity," "sustainability" of heritage use, "risks," "tourism pressure", and "tourism globalization."

b) Identify risks arising from mass tourism, globalization pressures, and different uses of heritage via press and literature review and a close analysis of selected case studies.

c) Identify heritage stakeholders who are also involved with tourism development (such as destination management organizations in historic cities, nonprofit organizations that manage heritage sites, administrators of cultural sites, and monuments that are open to 
the public as tourism attractions) and who could benefit from and contribute to the process of capacity building.

After this first step, in the near future we will be able to conclude and explore the perspectives and interests of those different stakeholders, their objectives, and strategies through semistructured face-to-face interviews or, where applicable, open-ended online questionnaires, in order to understand how tourism could improve the preservation of heritage, respect the diversity, and authenticity of the diversity of cultural values. Primarily, therefore, this project will facilitate an author review to complete the picture of the current situation and to find gaps and areas in need of theoretical support. A documental analysis will follow in order to capture the main concepts, compile the risks and opportunities of risk mitigation from selected international and European documents as well as stakeholders and professionals in relevant field selection. The documental analysis will identify the keywords that indicate the heritage values that could be disseminated in the proposed way to contribute to its safeguarding, conservation, and protection while improving the sustainability of its use.

Specific international and European documents, charts and declarations will help to deliver the above objective, such as Resolutions of the International Symposium on the Conservation of Smaller Historic Towns, at the 4th ICOMOS General Assembly (1975), Charter for the Conservation of Historic Towns and Urban Areas (1987), The International Cultural Tourism Charter (1999), the Nara Declaration (1997), ICOMOS (2013), International Cultural Tourism Charter-Managing Tourism at Places of Heritage Significance (1999), the Xi' an Declaration (2005), Xi'an Declaration on the Conservation of the Setting of Heritage Structures, Sites and Areas (2005), Faro Convention (2005), Council of Europe (2005), the European Charter for Sustainable Tourism in Protected Areas (2007), UNESCO (2008), the Charter for Interpretation and Presentation of Cultural Heritage Sites (2008), The Charter on Cultural Routes (2008), the Paris Declaration on Heritage as a Driver of Development (2011), ICOMOS (2011), and The Paris Declaration On Heritage as a Driver of Development (2011).

\subsection{HERITAGE VALUES AND RISKS}

All heritage tangible and intangible adds to the essence of places, landscapes, and memories, and represents aesthetic, historic, scientific, social, 
or spiritual values that justify its protection and preservation. The elements that give significance, importance, and emotion to places are transmitted from generation to generation, constantly recreated by communities and individuals as a response to what happens in the world around them and to the passage of history.

Those territorial elements, material or immaterial, are carriers of memories that are easily forgotten, destroyed or degraded. In this context, the debate must include the heritage conservation and valorization and the use by economic activities, in particular, tourism. Tourism and the other economic activities as well as the new uses of historical sites and monuments could be a threat but they could also improve the conservation and preservation of heritage (tangible or intangible) and promote the maintenance of cultural diversity.

Heritage is authentic, testimony of identity, significant, diverse, and coherent but it is also fragile, nonrenewable and irreplaceable, and often exposed to various threats. It is in these threats that the challenges of policymakers are crucial. Alteration, deterioration, disappearance, destruction, disruption, degradation, damaging, neglecting, transformation, and disrespect are keywords related with the heritage fragility emphasized in the successive international declarations and conventions (Fig. 6.1).

Natural causes are an enormous danger to heritage but the risks caused by the action of man are even more unpredictable. The natural reasons that can affect heritage include climate change, natural disasters, and the natural passing of time. They are exacerbated by other circumstances such as economic, social pressures, armed conflict, and cultural reasons.

Using the documental analysis of international charts and declarations, it is possible to identify other stress conditions that can be categorized into socio-economic and cultural. Inside the socio-economic category, mass tourism, globalization, economic pressure, speculation, social transformation, urban development, land use, pollution, traffic, and displacement of communities and abandoned places are the most-cited risks in international documents (Fig. 6.1). Among cultural factors it is not just the compatible new uses of heritage, its removal or demolition, loss of identity and character, disappearance of cultural practices, and loss or substitution of uses and values that are the most commonly cited threats in international documents (Fig. 6.1). 
Documental analysis of selected international and European charts and conventions by key words

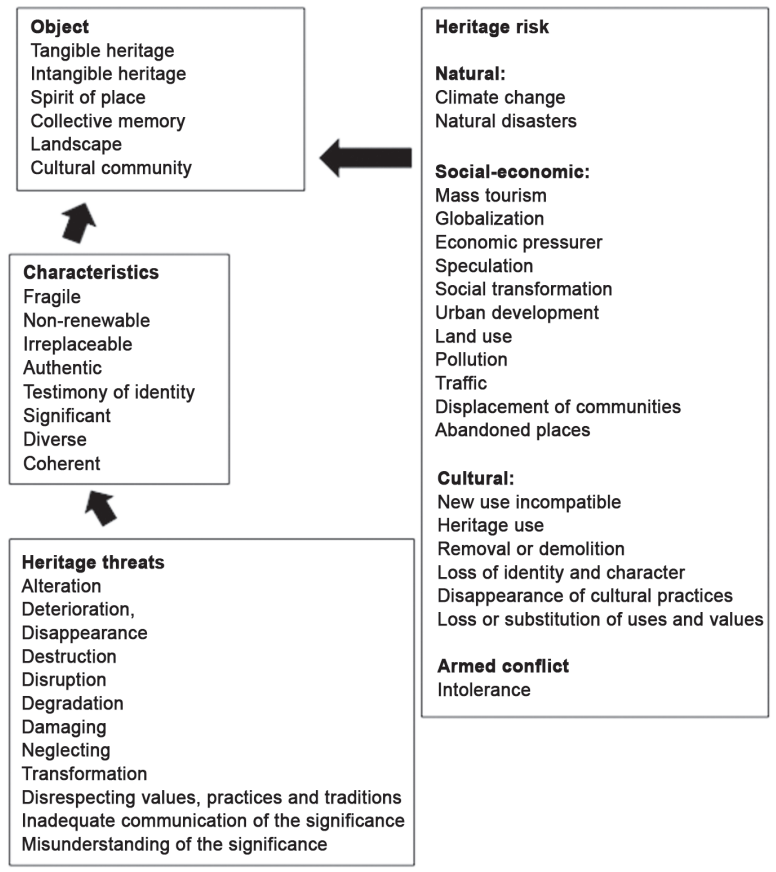

FIGURE 6.1 Heritage and the main risks.

Source: Diagram prepared by authors.

Necessary measures must be taken to ensure the safeguarding, protection, conservation, preservation, and prevention of negative impacts on the tangible and intangible heritage of the landscape, under the consequence of its loss, as soon as the economic evaluation of the territories has taken place.

Losing or decreasing the value of the place or the uniqueness of its character, its authenticity, the diversity of its attributes, and its deep significance, all those losses could jeopardize the meaning of a visit. It would make sense to issue a warning that losing or damaging heritage, one of the most important resources in the local and regional economy could negatively affect the motivation of local people to stay and in consequence lead to their abandoning the given territories. Without the stimulated involvement of local communities, places are affected by lethargy, inactivity, and forgetfulness of memory and heritage. The resulting local low self-esteem must be counteracted. 
Heritage protection becomes an ever-greater mission due to constant and numerous threats. Policymakers have to focus their action on the particularity of what identifies their territory and what gives it value by maintaining the spirit of hospitality that has given so much value to tourism, but at the same time they should implement measures to promote sustainability. In addition, special care and work should be undertaken to guarantee such heritage values as authenticity and identity. To explain the importance of authenticity, this concept refers to value-added travel, unprecedented experiences, discovering authentic places, discovery of traditional lifestyle, the desire to make the lived experience a way of life, identifying a population group, discovering vernacular architecture, and discovering of some unknown traditions.

Another risk which heritage may have to oppose are its new and incompatible uses and practices, loss or substitution of uses and values, and the removal or demolition of historical buildings, as well as the increase of new constructions. This loss of uses or values (tangibles or intangibles) could accelerate the movement of communities and the consequent loss of identity. Again, depopulation could have a serious impact on the territory.

In the interior of the country and in many rural areas, heritage often suffers neglect due to the vanishing of cultural practices and abandonment in the face of the departure of local communities, sometimes in relation to the processes of gentrification. Local decision makers need to be aware of the risks of gentrification and implement specific control systems to counteract it (ICOMOS, 2011).

It is necessary to limit or prevent the departure of local people, to promote their establishments, and to attract younger generations. Otherwise, the population decline and the changing social and economic conditions increase the risk of heritage damage or the destruction caused by the lack of economic investment to support its conservation or restoration.

Another factor that causes local communities to disperse is the incapacity of regional and local economies to create opportunities for entrepreneurship and to combat poverty. Policymakers actually are confronted with real territorial problems resulting from the fast economic development, in association with reduced planning for the sustainable development of places and insufficient measures to protect heritage and culture. It is very important to notice that the destruction of heritage, the identity and authenticity lost are correlated with economic, cultural, social, political activities and they threaten the wealth of the territory, as well as its 
values and significance. Contrariwise, heritage and culture could be treated as assets for local and regional development.

The risks caused by human actions, in particular, the development of mass tourism and the problems resulting from the fast urban development that lead to economic pressure and speculation are the most cited factors in the international documents. The increasing number of tourists generates a massive heritage use, in particular at historic urban centers, at World Heritage sites, and monuments. The increased tourist traffic affects urban development, worsens traffic conditions, and creates extra pollution.

Tourism opened a continuous process of global communication that carries social and cultural transformations and new possibilities of acculturation, creativity development, and cultural fusions. It is the passage of times that occurs as a living being. The new and the traditional may live together because together they enhance economic development and create cultural and social possibilities. But the threat of deterioration, disappearance, and destruction of tangible or intangible heritage is very present in this global process (UNESCO, 2003). Globalization, without concern for planning, vision, strategic thinking, and openness to the global world present itself as a strong threat. The natural resources and the use of heritage are heavily threatened, urging us to contemplate a sustainable development in our actions.

The tourism and heritage relationship is a very sensitive issue and sometimes a cause of disagreements between local and regional actors. One of the main reasons of the dissonance is that tourism and heritage have different perspectives about the use of heritage places. Heritage administrators are increasingly anxious about heritage tourism and accuse it for promoting an accelerating degradation of historical sites, buildings, and other structures. On the other hand, the tourism sector criticizes heritage administration for insufficient efforts to find a viable economic solution for the development and protection of heritage assets.

It should be noted that tourism has been the greatest ally in rehabilitation, conservation, safeguarding natural and cultural heritage in the motivation of communities, but it demands great responsibility from managers, policymakers, and society in general. As will be discussed later, heritage sites and historic towns are prone to overtourism. Tourism can improve conservation and the economic value of cultural heritage and could justify the preservation of cultural heritage and to educate communities and visitors alike. However, if tourism does not respect the 
intrinsic values of heritage, it can compromise its authenticity and damage its integrity. The development of tourism without particular concern for heritage values endangers the very characteristics of landscapes and the lifestyles of communities that drive it, ultimately degrading the overall visitor experience.

According to the analysis of charts and conventions, risk mitigation can be focused on an action centered on the territorial planning and management, on the protection of the heritage values, and the dissemination of the heritage significance through actions of formal and nonformal education (Fig. 6.2). These actions can promote protection and care for heritage assets, reduce negative impacts, and avoid the destruction of the elements that give value to the territory.

Documental analysis of selected international and European charts and conventions by key words

\begin{tabular}{|c|c|c|}
\hline Heritage risks & Risk mitigation & \\
\hline Natural: & Territorial planning and management: & \\
\hline Climate change & Territorial management & \\
\hline \multirow[t]{2}{*}{ Natural disasters } & Territorial planning & \\
\hline & International co-operation & \\
\hline Social-economic: & Participation local community & \\
\hline \multirow{2}{*}{$\begin{array}{l}\text { Mass tourism } \\
\text { Globalization }\end{array}$} & Control and monitoring measures & \\
\hline & Improve quality of the environment and the quality of way of life & \\
\hline \multirow{2}{*}{$\begin{array}{l}\text { Economic pressure } \\
\text { Speculation }\end{array}$} & Control gentrification & \\
\hline & Environmental sustainability & \\
\hline Social transformation & Emergency management and planning & Action \\
\hline Urban development & Sustainable development & Heritage safeguard \\
\hline \multirow{2}{*}{$\begin{array}{l}\text { Land use } \\
\text { Pollution }\end{array}$} & Coherent development & Heritage protection \\
\hline & Territorial cohesion & Heritage conservation and restoration \\
\hline \multirow{3}{*}{$\begin{array}{l}\text { Traffic } \\
\text { Displacement of communities } \\
\text { Abandoned places }\end{array}$} & Protection from climate change and natural disasters & Heritage preservation \\
\hline & & Prevent negative impacts \\
\hline & Culture and heritage values protection & Impacts monitoring \\
\hline \multirow{9}{*}{$\begin{array}{l}\text { Cultural: } \\
\text { New use incompatible } \\
\text { Heritage use } \\
\text { Removal or demolition } \\
\text { Loss of identity and character } \\
\text { Disappearance of cultural practices } \\
\text { Loss or substitution of uses and values }\end{array}$} & Bringing a live values (cultural, natural, traditional, historic) & Natural balance \\
\hline & In situ heritage protection & Avoiding the destruction of natural heritage \\
\hline & Compatible heritage uses & Planning facilities \\
\hline & Sustainable heritage use & \\
\hline & Harmonious adaptation to contemporary life & \\
\hline & Respect the values of the site and its setting & \\
\hline & Apply internationally recognized and appropriately standards & \\
\hline & Use of the cultural heritage economic potential & \\
\hline & Use of traditional material and techniques in modern applications & \\
\hline Armed conflict: & & \\
\hline \multirow[t]{6}{*}{ Intolerance } & Research, dissemination and educational needs & \\
\hline & Communicate the heritage significance & Concepts based action \\
\hline & Communicate the need of conservation for visitors and host & Cooperation and consultation of the host \\
\hline & $\begin{array}{l}\text { communitles } \\
\text { Include heritage in reasearch and in all education level's }\end{array}$ & Capacity building \\
\hline & Enhance access to cultural heritage through digitalization & Education and training opportunities \\
\hline & & Tourism promotion programmes \\
\hline
\end{tabular}

FIGURE 6.2 Risks mitigation.

Source: Diagram prepared by authors.

However, in order to achieve precise objectives in this respect that would benefit the territory and its people, it is important to involve all the 
stakeholders. They all need to develop their capacity through education and training.

The paramount economic function of tourism - its contribution to the "creation of wealth and employment," as pronounced in the Global Code of Ethics for Tourism (UNWTO, 1999) - is beyond doubt. The steady growth of the international tourism industry's share of the global GDP - amounting to $10 \%$ in 2017 , following a $5 \%$ rise over the previous year (UNWTO, 2018) - is one of the most eagerly quoted economic indicators. It has been observed, time and again, that tourism favors free-market conditions-in particular free enterprise, and the free flow of money, people, and goods, in order to maximize its positive socio-economic effects and to ensure an unencumbered utilization of key tourism assets.

With a short exception at the end of the first decade of the 21 st century, the global political and economic conditions have been particularly conducive for tourism and travel to flourish in most of their aspects. Nevertheless, the need to highlight the transformative power of tourism beyond the conventional economic indicators has also been advocated in the literature. Multiple evidence has been presented that tourism has the potential to promote peace, foster solidarity and tolerance, contribute to justice and social equity, enable cultural and intellectual exchange, increase the quality of life, trigger positive social changes, provide rationale for the conservation, protection and interpretation of buildings and the revitalization of traditions, etc. (Higgins-Desbiolles, 2006; Mason, 2016; Rivera et al., 2016; Sharpley, 2014; Smith and Diekmann, 2017). Arguably, the significance of cultural heritage tourism in this respect is greater than that of many other forms of leisure tourism (Council of Europe, 2005; Garrod and Fyall, 2000; McKercher and Du Cros, 2002; Rebanks, 2010; Richards, 2018; Silverman et al., 2017).

However, as a complex, global phenomenon, tourism has not been without its flaws. In fact, the very Code of Ethics was a necessary response to numerous cases of cultural and economic exploitation, social injustice, and environmental destruction caused by the industry around the world. A number of international and sectoral agreements and treaties, some of them discussed in this chapter, have addressed a variety of phenomena that undermine the net positive impact of tourism on people and places. The spectre of overtourism - that is, exceeding the carrying capacity of destinations, mainly those rich in cultural and heritage assets - has been but the latest threat borne out of the global quantitative success of the 
tourism industry (WTTC, 2017). Moreover, a number of communities and organizations around the world have been marginalized or altogether excluded from participating in the benefits of tourism due to their lack of knowledge, skills, or institutional mechanisms needed to utilize that potential (Silverman et al., 2017; Waterton and Watson, 2011). Digitalization has resolved some of the tensions resident in the discussed phenomena but it also brought about new challenges of exclusion based on digital literacy, as well as the as yet unresolved issue of misinformation (Taylor and Gibson, 2017).

The aim of this section is to identify and characterize the groups of interested or affected parties and/or individuals that have their stake in the tourism industry's deployment and expansion, and whose capacity-or lack thereof - to partake in the above can hinder or enhance the positive net effects of heritage tourism development.

\subsection{HERITAGE TOURISM STAKEHOLDERS IN SELECTED LITERATURE}

There have been many attempts to identify the social groups, institutions, and other parties that already do or potentially can participate in the sustainable development of cultural and heritage tourism. However, the perception of the role of various groups in this respect has markedly fluctuated since the 1980s (Richards, 2018). It has evolved from a traditional, top-down approach, that assumed the decisive role of experts and government agencies, to the current understanding that the key factor of successful and sustainable cultural tourism development are thriving local communities (Pollock, 2018).

The traditional, authoritative approach to heritage management, also encompassing heritage tourism and its stakeholders still linger in the practice of UNESCO, which, according to Lucas Lixinski, Vice-President of the Association of Cultural Heritage Studies, "falls short of bringing communities into the implementation of its cultural mandate" (Dore, 2018). A similar mindset dominates many intergovernmental and governmental agencies involved in heritage protection and management, and those active in the making and delivery of historical and educational policy, or in the organization and development of tourism (Harrison, 2013; Silverman et al., 2017; Waterton and Watson, 2011). It is marked by what Laurajane Smith 
famously called the Authorized Heritage Discourse (Smith, 2006), that is, a widespread belief that heritage resources can only be properly interpreted and evaluated by experts, especially at the international level. The concept has been widely discussed within the discipline of Heritage Studies (Ashworth and Howard, 1999; Fredheim and Khalaf, 2016; Silverman et al., 2017; Smith and Campbell, 2015; Throsby, 2001). Many authors point to the limitations of the approach, which has created an authoritative cultural canon of items, sites, and traditions that are protected and preserved at the expense of others, and often not for but against their potential use by various communities (Dore, 2018). Also, it seems to contradict the general trend toward democratization and broadening of the concept of culture itself, and in consequence also of cultural tourism, which has expanded away from traditional elite pursuits to embrace a mass market orientation (Richards, 2018).

Along with the critique of the Authorized Heritage Discourse and an improving understanding of the complex relationship between tourism and heritage, recently it has also been noted that the way various communities engage with cultural and heritage resources has changed over the years (Chabiera et al., 2017; Harrison, 2013; Ripp et al., 2017; Smith et al., 2012). Tourists are no longer seen as impartial, disaffected consumers, and host communities as complacent suppliers of tourism services. In fact, it has been noted that the essence of cultural tourism lies not in the fact of visiting cultural destinations, but in the experience to be had in the process (Smith et al., 2012).

The dominating business perspective in Tourism Studies means that there is scarce literature that would recognize the potential that lies in the encounter between tourists and local communities. In fact, the notion of such an encounter - and its consequences - is primarily an anthropological concept that lies outside the scope of expertise of most economics scholars (Nogués-Pedregal, 2019). Meanwhile, the failure to fully address the dynamics between hosts and visitors, the insiders and outsiders, affects our ability to understand and exploit the phenomenon of culture itself-and to maximize the potential of cultural and heritage tourism.

Thus far, most mainstream contributions on the subject of cultural tourism highlight its inherent dualism, visitors and locals, technology and tradition, protection and use, and profit and significance. The forces that shape the socio-economic processes of tourism seem to be in a continued and mutually competitive strive and the need-and 
possibility - to find the balance between them has only been uttered very recently (De Wilde, 2018).

As a matter of fact, both tourists and local communities seem to have grown weary of this traditional divide. The tourists' quest of authenticity has evolved from looking for exceptional experiences to the now prevailing search for "the everyday" (Richards, 2018). It is expressed in a growing number of offers to eat or live "like the locals," as well as in the recent rise of community-based or cooperative tourism business models. If not entirely successful, for example, due to deep cultural differences, the trend has at least resulted in the creation of "in-between" experiences in cultural tourism; encompassing elements that do not belong either in the local or in the tourist sphere (Richards, 2018).

At the same time, communities have been increasingly outspoken in their opposition to mass tourism, but the majority of destinations seem to have been unable to provide a comprehensive, scalable alternative. The recent insistence by New Zealand and Hawaii on attracting "better tourists," who would be willing to make real connections with locals - and generate more value to the economy - seem desperate and elitist at the core (Mathews, 2019). What seems to drive the tourist-local divide is a particular misunderstanding surrounding, at the street level, of the value of "the everyday." The antagonism is also often exacerbated by the relations of dependence created by international tourism (Nogués-Pedregal, 2019). At this point, it is worth noting that the transformative power of tourism extends also to places - towns, territories, and landscapes - thus, expanding the list of possible heritage tourism stakeholders to those, who are also direct and indirect users of those places.

In the face of necessity to move beyond the dichotomy of locals and visitors, it is herein proposed that heritage tourism stakeholders are seen as a spectrum, a network, ranging from insiders to outsiders and from the closest heritage communities to those that have the least attachment or involvement with it. Such view corresponds closely with a concept put forth by Ripp (2018), a Regional Coordinator at the Organization of World Heritage Cities, who suggested to approach cultural heritage as a system that principally belongs to local communities. Ripp distinguishes direct heritage users, indirect users, and influential parties - a classification that bypasses questions of power and emphasizes the aspect of heritage use (see Table 6.1). In this perspective local communities - the most immediate heritage users - are an essential element of the heritage system, a key 
stakeholder; tourists and trades have been classed as secondary users, and the remaining affected or interested institutions are mentioned as a tertiary, but influential, element of the system. Thus, by overturning the current system of power and directing attention toward the use value of heritage, which, at least from an economic point of view, has been the least troublesome of all the possible heritage values discussed in the literature, emerges a new categorization of heritage stakeholders, fitting for a study focused on the practical issue of capacity building.

Indeed, putting people at the center of the concept of heritage was also the core intention of the 2005 Faro Convention on the Value of Cultural Heritage for Society (Council of Europe, 2005). By emphasizing the changing and diverse needs of various heritage stakeholders, and empowering the original heritage users - the local people - the Faro Convention was a major step away from the rigid, linear, and authoritative heritage management approaches of the earlier era. It also emphasized that a sustainable approach demands that heritage continues to play a contemporary role - to be used - for the benefit of its various communities.

Table 6.1 shows the complexity of the heritage system seen this way. It has also been cross-referenced with the classification of heritage stakeholders according to the 2011 UNESCO recommendation on the historic urban landscape, which distinguishes three groups: communities, decision-makers, and professionals (UNESCO, 2011).

\subsection{CONCLUSIONS}

The approach of conservation and preservation of historical landscape as conservation and preservation of local memories through the symbolic elements of existing heritage is an important instrument for planners to avoid degradation or destruction of the local heritage. The geneses of perennial values are made during a long scale of time, including several successive stages of recognition and selection, projected on a time scale.

In this sense, it is significant to signalize the noteworthy heritage in a territory as a context of living societies in a certain place, and it is essential to create a methodology that can help to identify those important elements needing to be protected. It is imperative in any reflection about landscape and its constructions, to keep the line of thinking of the existent link created between natural and cultural elements. 
TABLE 6.1 Heritage Tourism Stakeholders.

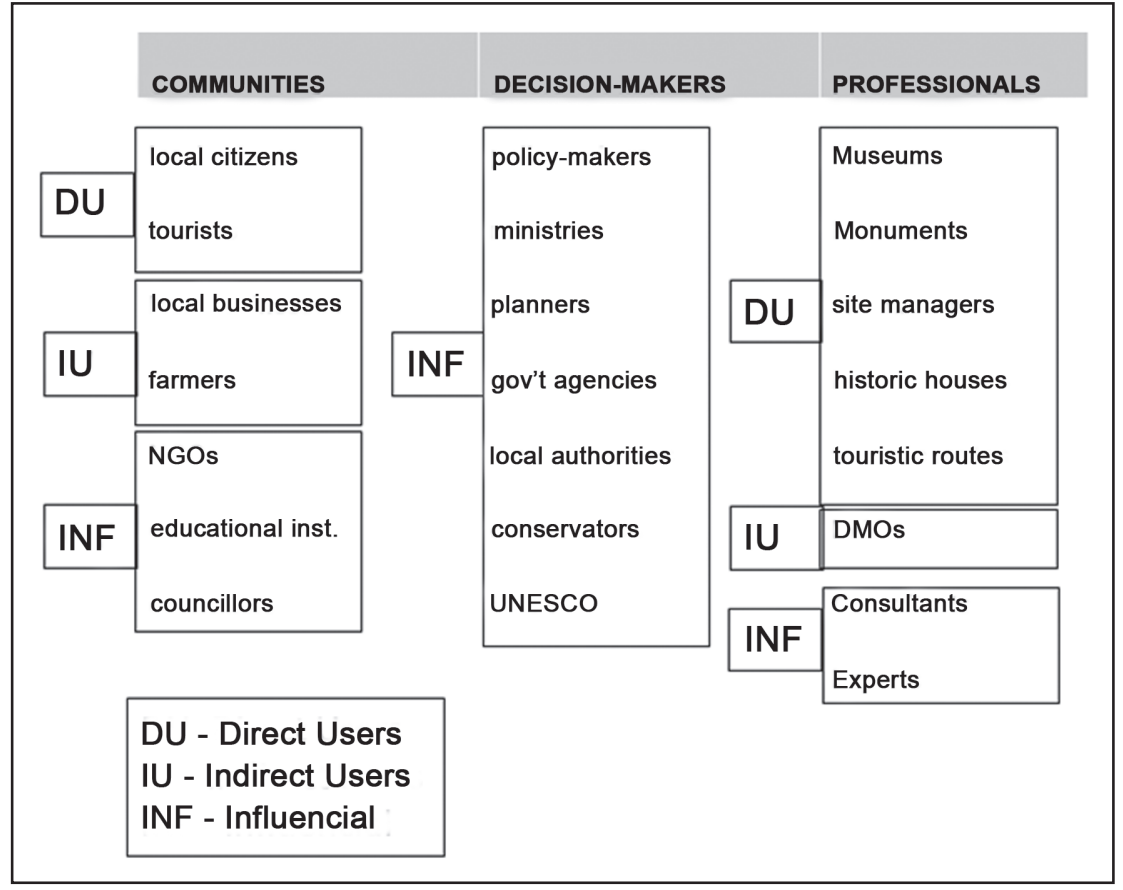

Source: Author's own compilation.

Every day the action of man shapes the landscape and the heritage resources which are testimonies of the passage of time in result of the human needs and "uses." The local history is changing at the turn of years and centuries and the historical landscape is in constant transformation due to the contemporaneity of human actions. In this context of historical evolution, the relation of man with the surrounding space that implies its transformation is very visible, a fact that could bring degradation or deterioration of the historical resources.

As an important economic resource, heritage must be valued and protected. It is not easy to decide or find alternatives to safeguard heritage, knowing that these cultural resources of the territory acquire enormous value and ample significance because they are active exporters of messages from the past. As elements of the territory that have persisted in the present time, they are living witnesses of the passing of several generations and 
bearers of a collective memory that we all have as a duty to protect for the future, as the UNESCO (1964) notes from an early date.

Various risks and challenges are constantly facing heritage, including natural disasters, economic development, tourism, pollution, inappropriate management, plunder, and war. It is important to emphasize the issue of economic development which exerts strong pressure on the cultural and natural resources.

At this moment, we are interested in addressing the decisions regarding the deliberation of actors involved in the processes of safeguarding the historical landscape, in particular changes arising from property impacts. It is necessary for the local managers to take into account the risks and pressures of their assets in order to act in accordance with international regulations and safeguard the traces of the past for future generations. In order to do so, it is necessary for local governments and managers to value and communicate this value so that it is known and preserved in the future, according to what it refers to. This is a way of building or developing capacities. Some of the risks bring about an irreversible transformation, both in nature and in the cultural landscape where elements of durability in time produced and produce the identity of cultures and societies.

The importance of heritage and the importance of historical and cultural landscapes to be preserved is not only because of their role as an important evidence to previous times and the source of a spirit of place, but because heritage and culture are important factors of territorial and economic development.

\section{KEYWORDS}

- heritage

- tourism

- sustainable development

- landscape

- conservation 


\section{REFERENCES}

Ashworth, G. J.; Howard, P. European Heritage Planning and Management; Intellect Books: Exeter, 1999.

Australia ICOMOS. The Burra Charter. The Australia ICOMOS Charter for Places of Cultural Significance; Australia ICOMOS Inc: Burwood, 1999.

Bourret, C. Cultural Heritage, Tourism, Identity and Sustainable Development of Territories: The Case of the Compostela Ways. In International Multidisciplinary Scientific Conference on Social Sciences \& Arts. SGEM, 2017.

Carroll, P.; Aarrevaara, E. Review of Potential Risk Factors of Cultural Heritage Sites and Initial Modelling for Adaptation to Climate Change. Geosciences 2018, 8 (9), 322.

Chabiera, A.; Dąbrowski, A.; Fortuna-Marek, A.; Kozioł, A.; Lubaś, M.; Nowak, P.; ... Stępnik, K. Polacy wobec dziedzictwa. Raport z badań społecznych; Warszawa, 2017.

Council of Europe. Council of Europe Framework Convention on the Value of Cultural Heritage for Society, 2005. http://conventions.coe.int/Treaty/EN/Treaties/html/199.htm.

Dans, E. P.; Gonzalez, P. A. The Altamira Controversy: Assessing the Economic Impact of a World Heritage site for Planning and Tourism Management. J. Cult. Heritage 2018, 30, 180-189.

De Wilde, P., Ed. Travel to Tomorrow; VISITFLANDERS: Brussels, 2018.

Dore, B. Who Controls Cultural Heritage?, 2018. https://hyperallergic.com/477859/whocontrols-cultural-heritage/ (accessed Feb 16, 2019).

Feria, J., Ed. Territorial Heritage and Development; London: CRC Press, 2012.

Francis-Lindsay, J. The Intrinsic Value of Cultural Heritage and Its Relationship to Sustainable Tourism Development: The Contrasting Experiences of Jamaica and Japan. Caribb. Q. 2009, 55 (2), 151-168.

Fredheim, L. H.; Khalaf, M. The Significance of Values: Heritage Value Typologies Re-examined. Int. J. Heritage Stud. 2016, 7258 (April). https://doi.org/10.1080/13527 258.2016.1171247.

Freitas, I.; Cortés, R. E.; Leite, P. P. A Methodological Proposal for Building Conservation: A Case in Guimarães, World Heritage City. In Conservation and Promotion of Heritage Tourism, 2018; pp. 57-86.

Freitas, I.; Martín Cea, J. C.; Villanueva Zubizarreta, O.; Val Valdivieso, I. Abordagem metodológica de conservação da história e do patrimônio: O Vale do Douro. Revista Tempo e Argumento 2017, 9 (21), 99-125.

Garrod, B.; Fyall, A. Managing Heritage Tourism. Ann. Tour. Res. 2000, 27 (3), 682-708. https://doi.org/10.1016/S0160-7383(99)00094-8.

Guzmán, P. C., Pereira Roders, A.; Colenbrander, B. J. (2017). Measuring Links between Cultural Heritage Management and Sustainable Urban Development: An Overview of Global Monitoring Tools. Cities 2017, 60 (A), 192-201.

Harrison, R. Heritage. Critical Approaches; Routledge: London, 2013.

Helly, D. Scenario Configurations for the EU as a Cultural Heritage Protection Actor in Armed Conflicts. J. Cult. Heritage 2018, 33, 271-277.

Higgins-Desbiolles, F. More than an "industry": The Forgotten Power of Tourism as a Social Force. Tour. Manage. 2006, 27 (6), 1192-1208. https://doi.org/10.1016/j.tourman. 2005.05.020. 
ICOMOS. The La Valletta Principles for the Safeguarding and Management of Historic Cities, Towns and Urban Areas; La Valletta, 2011.

ICOMOS. The Australia ICOMOS Charter for Places of Cultural Significance, the Burra Charter; Australia, 2013.

Koskowski, M. R. Castles as a Particular Tourist Product. Forum UNESCO University and Heritage, 10th International Seminar Cultural Landscapes in the 21st Century; Newcastle upon Tyne, 2006; pp. 11-16. http://conferences.ncl.ac.uk/.

Koskowski, M. R. Dziedzictwo kulturowe w przestrzeni turystycznej na przykładzie zamków w Polsce. In Ożywianie przestrzeni turystyki kulturowej; Ostrowski, D., Ed.; Wyższa Szkoła Turystyki i Języków Obcych: Warszawa, 2017; pp. 69-83.

Kourilova, J.; Pelucha, M. Economic and Social Impacts of Promoting Cultural Heritage Protection by the Czech Rural Development Programme 2007-2013. Eur. Countryside 2017, 9 (3), 486-503.

Lwoga, N. B. Dilemma of Local Socio-economic Perspectives in Management of Historic Ruins in Kilwa Kisiwani World Heritage Site, Tanzania. Int. J. Heritage Stud. 2018, 24 (10), 1019-1037.

Mason, P. Tourism Impacts, Planning and Management; Routledge: London, 2016.

Mathews, J. Hawaii Doesn't Need More Tourists, It Needs Better Tourists. Zócalo, 2019. http://www.zocalopublicsquare.org/2019/02/22/hawaii-doesnt-need-tourists-needsbetter-tourists/events/the-takeaway/.

McKercher, B.; Du Cros, H. Cultural Tourism : The Partnership between Tourism and Cultural Heritage Management; Haworth Hospitality Press: London, 2002. https:// books.google.pl/books?id=9FxsBgAAQBAJ.

Nogués-Pedregal, A.-M. Anthropological Contributions to Tourism Studies. Ann. Tour. Res. 2019, 75, 227-237.

Petroman, C.; Iancu, T.; Popescu, G.; Iosim, I.; Csaholczi, A.; Marin, D.; Vaduva, L. Directed Authenticity in Tourism. LUCRĂRI ŞTIINŢIFICE n.d., 20 (1), 172-176.

Pierantoni, L. Governing Regional Development through Culture and Creativity: The Case of the Veneto Region. Eur. Plan. Stud. 2015, 23 (5), 963-978.

Pollock, A. Towards a Flourishing Destination. In Travel to Tomorrow; De Wilde, P., Ed.; VISITFLANDERS: Brussels, 2018; pp. 16-17.

Rebanks, J. The Price of Lemons - World Heritage and Economic Development. Interview with James Rebanks. World Heritage 2010, 58, 79-82. www.pfdheritage.com/wh58.

Richards, G. Cultural Tourism: A Review of Recent Research and Trends. J. Hosp. Tour. Manage. 2018, 36, 12-21. https://doi.org/10.1016/j.jhtm.2018.03.005.

Ripp, M. Heritage as a System and Process that Belongs to Local Communities. Reframing the Role of Local Communities and Stakeholders, 2018. https:/www.researchgate.net/ publication/325398758_Heritage_as_a_System_and_Process_that_Belongs_to_Local_ Communities_Reframing_the_role_of_local_communities_and_stakeholders.

Ripp, M.; Goettler, M.; Scheffler, N., Eds. Community Involvement in Heritage Management; Organisation of World Heritage Cities: Regensbur, 2017. https://www.researchgate.net/ publication/318531316_Community_Involvement_in_Heritage_Management_-_Guidebook.

Rivera, M.; Croes, R.; Lee, S. H. Tourism Development and Happiness: A Residents' Perspective. J. Dest. Market. Manage. 2016, 5 (1). https://doi.org/10.1016/j.jdmm.2015.04.002. 
Scheyvens, R. Tourism for Development: Empowering Communities; Prentice Hall: Harlow, 2002.

Seminara, G.; Sgamellotti, A. Resilience of Cultural Heritage to Natural Disasters: The Recent Involvement of Science Academies. Abitare La Terra 2017, 16 (42/43), 47-49.

Sharpley, R. Host Perceptions of Tourism: A Review of the Research. Tour. Manage. 2014, 42, 37-49. https://doi.org/10.1016/j.tourman.2013.10.007.

Silverman, H.; Waterton, E.; Watson, S., Eds. Heritage in Action; Springer International Publishing: Cham, 2017. https://doi.org/10.1007/978-3-319-42870-3.

Smith, L. Uses of Heritage; Routledge: Abingdon, 2006.

Smith, L.; Campbell, G. The Tautology of "Intangible values. ” Australian National University: Canberra, 2015. http://www.canberra.edu.au/research/faculty-research-centres/cccr/ resources/insignificance

Smith, L.; Waterton, E.; Watson, S., Eds. The Cultural Moment in Tourism; Routledge: London, 2012.

Smith, M. K.; Diekmann, A. Tourism and Wellbeing. Ann. Tour. Res. 2017, 66, 1-13. https:// doi.org/10.1016/j.annals.2017.05.006.

Taylor, J.; Gibson, L. K. Digitisation, Digital Interaction and Social Media: Embedded Barriers to Democratic Heritage. Int. J. Heritage Stud. 2017, 23 (5), 408-420.

Throsby, D. Economics and Culture. Cambridge University Press: Cambridge, 2001.

UNESCO. The Venice Charter for the Conservation and Restoration of Monuments and Sites; Venice, 1964.

UNESCO. Convention Concerning the Protection of the World Cultural and Natural Heritage; Paris, 1972.

UNESCO. Convention for the Safeguarding of the Intangible Cultural Heritage; Paris, 2003.

UNESCO. Québec Declaration on the Preservation of the Spirit of Place; Québec, 2008.

UNESCO. Recommendation on the Historic Urban Landscape; Paris, 2011.

UNWTO. Global Code of Ethics for Tourism; Santiago, 1999. http://cf.cdn.unwto.org/sites/ all/files/docpdf/gcetbrochureglobalcodeen.pdf.

UNWTO. Tourism Highlights 2018; Madrid, 2018.

Vecco, M.; Imperiale, F. Cultural Heritage: Values and Measures: What Insurance Value? J. Multidiscip. Res. 2017, 9 (1), 7-22.

Vinuesa, M. A.; Torralba, L. Visión territorial del patrimonio y sostenibilidad del turismo. Boletín de La Asociación de Geógrafos Españoles 2018, 78, 212-244.

Waterton, E.; Watson, S., Eds. Heritage and Community Engagement. Collaboration or Contestation? Routledge: London, 2011.

WTTC. Coping with Success. Managing Overcrowding in Tourism Destinations, 2017. https://www.mckinsey.com/industries/travel-transport-and-logistics/our-insights/ coping-with-success-managing-overcrowding-in-tourism-destinations.

Zhu, Y. Uses of the Past: Negotiating Heritage in Xi'an. Int. J. Heritage Stud. 2018, 24 (2), 181-192. 
